\title{
Hermeneutics, Poetry, and the Irony of Plato
}

Travis Foster

Baylor University

\section{Introduction}

In Book X of Plato's Republic, Socrates considers whether or not to exile poetry from the ideal polis. He settles on a provisional answer in the affirmative, but he makes the following concession:

Then we'll allow its defenders, who aren't poets themselves but lovers of poetry, to speak in prose on its behalf and to show that it not only gives pleasure but is beneficial both to the constitutions and to human life. Indeed, we'll listen to them graciously, for we'd certainly profit if poetry were shown to be not only pleasant but beneficial (X, $607 d-e)$. $^{\prime}$

Tension arises, however, because Plato is himself a poet, an artisan with words. How can this tension, almost a contradiction, be resolved? In this essay I will take up Socrates' challenge to construct a philosophical justification for permitting poetry, and show how poetry does prove beneficial to human life. ${ }^{2}$ This explanation dissolves the apparent tension in the Republic. In order to construct my defense of poetry, I employ the philosophical hermeneutics of Hans-Georg Gadamer, and in particular his investigations into the truth of art. Gadamer's hermeneutical insights unveil Platonic epistemology and metaphysics, allowing us to see Plato not as a writer in conflict with himself, but as a poet ironically crafting his own work of genius.

The discussion to follow consists of four sections. The first two sections explore the Greek concepts of mimesis and phronesis, both of which are central in the works of Plato, Aristotle, and Gadamer. The third section examines more closely the relationship between poetry and philosophy, focusing on concepts de- 
scribed in the first two sections and using them to articulate a defense of poetry. I also answer the suggestion that my idiomatic use of phronesis unjustifiably conflates the philosophies of Plato and Aristotle. The last section is a discussion of Plato himself as a poet behind all of his philosophizing, in order to say just how this fact plays into his criticisms of poetry and art.

\section{Part I: Mimesis}

A cursory summarization of Plato's motivation for exiling poets might take the following form. The main problem with poetry, as he relates in Book III, is that it simultaneously tends to praise the gods and accuse them of bad behavior, including drinking and womanizing to excess, and exhibiting behavior that would be destructive to the polis if the citizens were to follow these models. Plato goes so far as to say that the members of the polis are not to believe such things, even in the poetry of the much-esteemed Homer, because such behavior obviously could not be attributed to gods worthy of praise and sacrifice. Furthermore, epic heroes who are the offspring of the gods should be distanced from human failings as well. Socrates concludes that,

We'll compel the poets either to deny that the heroes did such things or else deny that they were children of the gods. They mustn't say both or attempt to persuade our young people that the gods bring about evil or that heroes are no better than humans. As we said earlier, these things are both impious and untrue, for we demonstrated that it is impossible for the gods to produce bad things (III, 391d-e).

However, this is a superficial reason for the strict regulation of poetry in the polis. A deeper problem is that poetry tends to make heavy use of mimesis, or imitation. As imitation, poetry is far down the ontological/ epistemological dividing line that Plato draws in Book VI. Poetry, as art, imitates the things that a craftsman makes, which are themselves only imitations of the Forms that the philosopher-king discovers. Plato writes, 
We hear some people say that poets know all crafts, all human affairs concerned with virtue and vice, and all about the gods as well. They say that if a good poet produces fine poetry, he must have knowledge of the things he writes about, or else he wouldn't be able to produce it at all. Hence, we have to look to see whether those who tell us this have encountered these imitators and have been so deceived as to realize that their works are the third remove from that which is and are easily produced without knowledge of the truth... (X, 598d599a).

Plato asserts that if poets really had knowledge of the things about which they wrote and sang, then they would be far more inclined to act in ways that would make them the subjects of eulogies rather than their authors. In other words, they would act virtuously if they knew what virtue was, rather than sing its praises. In this case, poets would no longer be poets; they would be philosopher-kings. Hence, Socrates recommends regulating the subject matter of poets: they do not know what they are talking about, because they are too enmeshed in their own mimesis.

Yet is Plato against mimesis in all of its forms, against everything that imitates? This conclusion is hardly supported by his writings. One of Plato's overriding concerns in the Republic is the constitution of the perfect city, because it reflects the human soul in harmony. Part of Plato's concern appears in his discussion of how the youth of the city should be educated. His primary objective in censoring the subject matter of the poets is to prevent the dissemination of false ideas of virtue to impressionable minds. Taking this concern as pivotal, one sees that it is not mimesis itself that worries Plato, but sophistic textual manipulation. As Rod Coltman writes, Plato "concerns himself primarily with the moral and pedagogical effect of mimetic poetry on the human soul."." Thus Plato is not so much cautioning against mimesis itself, as he is condemning the way it is used, particularly by the Sophists, who often resort to citations of epic poets. Texts as infinitely rich as those of Homer, for example, are ideal templates for abusive inter- 
pretations that can be used to manipulate others and "make the weaker argument appear the stronger." To settle this tension between mimesis and its effects requires introducing the hermeneutic dimension. This line of inquiry brings us to the philosophy of Gadamer.

Gadamer distinguishes between two forms of mimesis: the aesthetic and the properly pedagogical. ${ }^{+}$The aesthetic mimesis is full of passion and stirs up the soul. He calls this "mere" imitation, and it is this form that Plato wamed against in the Republic. The properly pedagogical form, however, is more like an invitation. When one imitates in this way, one is observing the actions of another in order to learn how to perform a certain activity. Assimilation is involved here, because imitators imitate for the express purpose of making the action their own. In such instances they are "not subject to and at the mercy of inadvertent and arbitrary mimetic influences, but [are themselves] intentionally immersed in imitation of that which [they] consciously perceive to be beneficial to [them], like philosophical dialogue, for example."s A difference in emphasis and in the role of the audience separates the two modes of imitation. Aesthetic mimesis concentrates on what is said and demands submission to the text as an authority; such-andsuch is so because the text says that it is so. The audience is there to be persuaded, and they are persuaded because they mutually recognize the supremacy of the text. Properly pedagogical mimesis, however, places emphasis not on what is said or done, but on how something is said or done. The audience is treated not as a group of judges to be persuaded, but as a class of students willing to learn. Thus the text points beyond itself to a future time, and to future performances by those who learn from it. The aesthetic mode is caught in the present, where its effects come to an end once the audience has been placed under submission and persuaded.

If Homer is the poet par excellence (as Plato believed), then his oral works can be imitated in two ways. They may be used as accounts of the behavior of the gods, their children, and of the ancestors of the Greek people. Such imitation (aesthetic) treats the epic poems as static historical artifacts, or as fossilized records that may be used to influence decisions about everything from law to ethics and education. Therefore, aesthetic mimesis treats poems 
as sources of authority that are used to further the poet's typically political ends." The second way to imitate the works of Homer, however, involves Homer himself. The poet interacts with Homer, with the singers of Homeric poetry that have handed down those ancient songs, and with the words that weave those tales of gods and heroes. Instead of using Homeric poetry as an authoritative history, poets who engage in properly pedagogical mimesis are more concerned with their own role in a tradition, the tradition that is Homer. When poets imitate in this way, they come to the realization that to be a part of a tradition bears with.it the responsibility of seeing that tradition survive into the future; hence these poets involve their audience in order to ensure the survival of the process that is Homeric poetry.

Thus, what is wrong with the aesthetic mode of mimesis is that it alienates both imitator and audience by calling attention to the text as the locus of authority. Both aesthetic and properly pedagogical mimesis are actions, not things. However, aesthetic mimesis objectifies the action by calling attention to the effects of what is done rather than to its affects; that is, the objectification makes the text a concrete thing that has the effect of holding power over the audience. Properly pedagogical mimesis, however, is gauged by how it affects the student that is learning, and how such an affected student uses the knowledge that is understood from the instruction. Properly pedagogical imitation always involves the interaction of the poet and the audience, or in hermeneutic language, of text and interpreter. There is no forgetting of self; indeed, one cannot get beyond oneself. ${ }^{7}$

This distinction is crucial, for in defending poets I must demonstrate both that they are able to occasion such an invitation of properly pedagogical mimesis and show how they go about it. One consequence of failing to differentiate between the two modes of mimesis is that philosophers offer near-sighted interpretations of Plato that dub him either a "failed poet" or a "puritan" who "feared" poetry because he feared pleasure, as Iris Murdoch has suggested. Such Freudian misreadings of Plato miss the point. If the properly pedagogical mode of mimesis is, as Coltman describes it, analogous to philosophical dialogue, then poets might not be as different from philosopher-kings as Socrates first supposed. 
In Book VI of the Republic Plato offers his account of the good by having Socrates describe it as something like the sun. The light that shines forth from the sun might be similar to what we would call truth, and objects of knowledge are grasped by the human soul because of their illumination by the truth radiating from the sun. Plato writes:

Well, understand the soul in the same way: When it focuses on something illuminated by truth and what is, it understands, knows, and apparently possesses the understanding...so that what gives truth to the things known and the power to the knower is the form of the good. And though it is the cause of knowledge and truth, it is also an object of knowledge (VI, 508d-e).

Plato also contends that the Forms, or highest objects of knowledge, depend on the one ultimate Form, the Good, for their existence. Philosopher-kings, whose business it is to know the Forms, take a special interest in knowing the Good. After all, their privileged access to the Forms makes them suitable discoverers of what virtue is, and arbiters of how the members of the polis are to live virtuously. The question then becomes, how do philosopher-kings come to understand the Forms, and especially the Form of the Good, so that they can discover in what virtue consists. Defending the poets requires showing that the philosopher-kings do not in fact have sole privileged access to virtue and the Forms. My argument attempts to demonstrate that the poetic and the philosophical ways of getting at the truth are not as different as they might seem. First, however, I must discuss the use (and relevance) of phronesis by the thinkers we are examining.

\section{Part II: Phronesis}

Plato says that access to the Forms is gained by exercising one's reason appropriately. As the highest division of the soul, reason can be used to understand the Forms through philosophy (hence philosophers are the natural candidates for leaders of the city). Noesis, or understanding, goes hand in hand with proper rea- 
soning. Taking this fact as a starting point, modern philosophy has attempted to confine such an exercise of reason to a method. To see how Gadamer's philosophical hermeneutics addresses the problems of understanding (while avoiding the standard recourse to method), requires tracing his hermeneutical enterprise back to its phenomenological roots. Phenomenology began as the pursuit of the right method for grasping the noetic features of objects in an effort to get noesis "right." I briefly examine the method suggested by Husserl for arriving at such a perfect understanding, and explain how Gadamer, like Heidegger before him, changed the rules of phenomenology so that the pursuit of truth had less to do with method and more to do with the Aristotelian notion of phronesis. Finally, I show how this Gadamerian idea of understanding based on interpretation is closer to what Plato had in mind than others, such as Husserl, had thought.

Husserl began construction of his phenomenological method convinced that if he could somehow perfect the way we come to understand what something is we would be able to "get it right" and secure the foundations of the natural sciences. He employed the phenomenological reduction, sometimes also called the "eidetic" reduction. Its goal was to get at the eidetic (i.e., universal) features of particular experiences. Phenomenology was a method crafted to uncover what it was to have an experience of a certain something. During the phenomenological reduction, an experience is initially had in what Husserl called the "natural attitude," or the pre-philosophical way of looking at things with our various assumptions of its character and being. Under the reduction, however, these assumptions and pre-conceived notions of the ontological status of the experience are "bracketed," or set aside, while still holding the object of consciousness "in retention." In doing so, the phenomenologist hopes to act intentionally as a transcendental ego, or pure subject that encounters an object of intentionality without any ontological commitments. This method of looking at our experience is the way to "get it right" because it leaves behind all of the contingencies, all of what Gadamer calls the "history of effects" of the subject. Husserlian phenomenology is thus often called "transcendental" phenomenology. 
Heidegger had noted that the world often presents us with a certain amount of "resistance," or a power to draw us into it and prevent the kind of transcendence Husserl had sought. He devoted the majority of his early works to shifting the focus of phenomenology from the primarily epistemological concerns of transcendental phenomenology to more ontological considerations: Heidegger wanted to find out what Being is. Being, however, could be analyzed only in terms of its occurrence within a world, something that Heidegger called "being-in-the-world." Heidegger brought to the attention of Husserl the fact that being-in-the-world could not be ignored if phenomenology was to survive. Gadamer notes that as a result of Heidegger's influence, "Husserl was able to acknowledge being-in-the-world as a problem of the horizon intentionality of transcendental consciousness, for the absolute historicity of transcendental subjectivity had to be able to demonstrate the meaning of facticity." This "facticity" that had to be considered is the entirety of contingent details of one's life that creep in when doing any transcendental analysis, even Husserl's phenomenological reduction. Being is always (but not only) factical in that it is always already "headed over into a world." In other words, it is always in a particular time, moment in history, place, and so forth. Gadamer focuses on something perhaps even more fundamental: if we are going to talk about the Being of beings at all, or any other object of consciousness, then we must realize that in doing so what we are really accomplishing is the construction of an interpretation.

Gadamer, like Heidegger before him, had doubts about Husserl's ideas because they tended to neglect life and its "speculative demands." The Husserlian project, as Gadamer notes, "attempts to derive the constitution of the historical world from "conscious life'... [but] we might ask whether...the genuine content of the concept of life does not become alienated when it is articulated in terms of the epistemological schema: deriving it from the ultimate data of consciousness." "I" Furthermore, other people are apprehended under the Husserlian method as objects of consciousness, each of whom is only subsequently realized as a "Thou" through empathy. Gadamer thinks that this consequence renders the method faulty because the "Thou" must be included in an "im- 
mediate and primary way." Gadamer's concern here is that Husserl left out crucial factors in describing human understanding, not the least of which is the understanding that arises through interaction with a community. When we are constantly trying to overcome our historical circumstances and the commitments foisted upon us by tradition, we lose sight of the existential dimension of life, and we become "alienated." Gadamer accepts these existential factors as necessary and does not try to transcend them in an effort to reach the "ultimate data of consciousness." While he criticizes the hermeneutic tradition for its dogged pursuit of its own method, he does not give up on truth.

When Aristotle speaks of phronesis, or ethical knowledge, he says that it cannot be taught to the young the same way other subjects can because it is acquired through experience. Young people must interact with the world, and in doing so they engage in the process of learning what is right and what is wrong. Why does phronesis resist the ability to be taught methodologically? As Coltman points out,'2 Book VI of the Nichomachean Ethics may provide a clue:

What has been said is confirmed by the fact that while young men become geometricians and mathematicians and wise in matters like these, it is thought that a young man of practical wisdom [phronesis] cannot be found. The cause is that such wisdom is concerned not only with universals but with particulars, which become familiar from experience, but a young man has no experience, for it is length of time that gives experience... ${ }^{13}$ (VI, 1142a, 12-16).

From this passage Aristotle seems to think that ethical knowledge cannot be taught in the same way as mathematical formulae because unlike geometry and mathematics there is no method to the learning of ethical rightness. ${ }^{\text {" }}$ Phronesis involves a "non-methodical deliberative process that is tempered by experience" that "does not consist in a computational formula that can be applied indiscriminately to any particular situation."15 Gadamer takes this idea 
as the basis for his resistance to method of philosophical hermeneutics in Truth and Method, as he sees all interpretation as a kind of phronesis.

Gadamer contrasts ethical knowledge with the ethical sciences in an effort to explain why Aristotle wrote the Nicomachean Ethics despite the impossibility of teaching ethical knowledge. As Coltman writes, "the ethical sciences, of which Gadamer sees the Nicomachean Ethics itself as a prime example, provide only general outlines or schemata that may help guide the moral person. But, he argues, even the teacher of ethics 'always already stands within an ethical-political restriction from out of which he acquires his image of the matter [die Sache; i.e., the moral idea to be achieved]."I6 As an ethical scientist, Aristotle knew that ethical knowledge was not able to be "confined to one easily circumscribable domain," so he did not bother to work out a method with which we clear the way for the "smooth ground of theory" that allows for ethical knowledge a priori. ${ }^{17}$ Instead, he wanted to point his readers in the right direction of arete ethike (moral excellence). The products of ethical science (e.g., the Nicomachean Ethics) are the products of techne; as such, they fail to capture the heuristic aspect of phronesis. ${ }^{\mid \mathrm{x}}$ It is just this heuristic dimension of ethical learning that evades methodological instruction as practiced by the geometer and mathematician.

Ethical knowledge, as the process of phronesis, is gained by experience. But this is not as simple as going out and listening to the opinion of the majority, or behaving according to socially accepted norms. The experience necessary for phronesis is an opening up towards the truth of one's experience, a comportment towards letting things appear as they are. This "openness" is what Gadamer calls the "art of questioning." We ask questions of others because the activity that we are engaged in, phronesis, has as its goal understanding. We preserve our openness when we can persistently ask the right questions. Hence, experience is not so much an empirical science as it is an orientation, one that permits being "radically open and ready for new experiences and capable of learning from them." ${ }^{\text {"O }}$ The orientation is not a personal prerogative to be liberal in one's views, though this is a possibility of its effects; it is what Heidegger would call a way that Dasein can 
"be-in-the world." Aristotle saw the inability to teach ethics and mathematics in the same way as a reflection of the immaturity of students' youth. They have not lived long enough to become "cultured," a process that Gadamer (following Hegel) calls Bildung. Gadamer takes this Aristotelian point about the limits of knowledge and brings it into the realm of Heideggerian ontology, where individuals' ways of being dictate their ways of understanding the world. Our practical understanding arrives at "knowledge [that] does not have the rank of episteme understood as a pure objective cognition detached from the kind of human beings which we are."2। The orientation is dialectical in that it has a "negative element", one that "springs from the knowledge of not knowing" in the "spirit of Socrates." 2 We are engaged in phronesis whenever we encounter the world in its particularity and attempt to understand its truth.

Phronesis resists method, and it is a process in which we are always already engaged. Gadamer argues that interpretation is similar. Brice Wachterhauser writes that "phronesis is paradigmatic for interpretation, according to Gadamer, because it involves a constant movement between a universal meaning-claim and particular circumstances."'3 Aristotle knew that no amount of teaching would take his students to the "truth" about the virtuous life, not because he did not know what it was, but because it was always changing and based upon circumstance: Wachterhauser notes that the "ethical universal itself [is] somewhat inexact." $2+$ What makes this account of phronesis "paradigmatic" for interpretation is that when we interpret a text-in the loose Gadamerian sense of anything that contains a richness of meaning to be drawn out-we are not trying to get at its fixed "essence." Indeed, fixed essences cannot be the objects of our investigation because a text changes over time with each new valid interpretation. Wachterhauser writes, "The being of the universal is increased in application to a particular set of circumstances because its meaning becomes, in principle, fuller, more complete with each new genuinely defensible application of it."2s Insofar as Gadamer is still a Platonist, he holds that the "essence" of the text, while not static, exists and undergoes a process of increase in being with each new interpretation. This increase is not a change per se, but an "adding to." The richer the text, the more infinitely expandable it becomes through inter- 
pretation. No distinction appears between epistemology and metaphysics in Gadamer's philosophy, such that we might object that the "increase" going on is merely an increase of our knowledge about a universal. Instead, the ontological "increase" is symbiotic with our knowledge of the text in question.

The classical reading of Plato is already at odds with Gadamer's reading; it would never accept the idea that Forms undergo an increase in being because this conflicts with their "eternality." However, Gadamer makes an even more radical claim: the increase in being through interpretation does take into consideration interpreters and their histories. Phronesis not only "captures" the metaphysical operations of interpretation, but also the problem of the effect of the subject's history on experience that troubled Husserl and Heidegger. The bearing of a text on my own circumstances Gadamer calls "application." The Forms (in Gadamer's account) are not seen as removed from the circumstances of language, experience, and the situation of the subject. We not only take into our interpretation our Wirkungsgeschichte ("history of effects") which includes our cultural heritage, our education, etc., but our doing so is necessary for adequate interpretation.

When one interprets a text, a "fusion of horizons" occurs in which a personal history interacts with a text to derive a meaning, a common act of participation that affects and defines both it and oneself. ${ }^{26}$ Just as in ordinary parlance a horizon is the limit of what one is able to see, the "horizon" of interpreters or a text is their particular situatedness. Individuals' abilities to "see" are based upon their finite experiences and histories, and the textual horizon projects from the finiteness of its physical aspect (the words on the page, for example). When the fusion occurs in proper interpretation, all horizons involved "expand"; interpreters add understanding of the text to their history of effects, and the text undergoes an increase in being, or a growth in the ways in which it can be said to mean something. Wachterhauser writes, "Only by engaging in this mediation [application] can I begin to grasp these realities themselves as they really are, i.e., as realities whose meanings are connected to our language and experience in essential ways and which evolve over time in constant dialogue."'7 This "dialogue" is be- 
tween myself, authors and their experiences, and texts, where all of these horizons merge and participate in the Form of the text.

\title{
Part III: Philosophy, Poetry, and Metheris
}

How does philosophical hermeneutics as described by Gadamer and phronesis that is integral to it relate to Plato's discussion of the poets? If we consider that Plato thought of dialectic as the way to do philosophy, then the answer is clear. For what is dialectic except dialogue, a series of questions and answers among interlocutors who have to engage in properly pedagogical mimesis to achieve phronesis? Dialectic arises as a form of participation (methexis) among speakers, in the same sense in which particulars participate in a Form. As each new interpretation of a text increases its being, each new instantiation of a particular increases the being of the Form to which it corresponds. Similarly, the respective persons engaged in dialogue achieve an increase in their Being by participation, as I intimated earlier.

I described the properly pedagogical mimesis as a kind of invitation that Gadamer describes as openness, which is essential to dialogue and to methexis. Gadamer explicates openness in this way:

\begin{abstract}
But this openness is, in the end, not there only for the person from whom we wish to be told something; rather whoever in general allows something to be told to him is, in a fundamental way, open. Without such an openness to one another there is no genuine human bond. ${ }^{2 k}$
\end{abstract}

Part of this openness consists in each participant being open to surprise; each must be open to the risk of being wrong. Husserl would have objected to this claim, for the whole idea of Husserlian phenomenology was to arrive at certain knowledge of the eidetic features of our experiences. Gadamer, on the other hand, knows that we carry with us pre-conceived commitments (ontological and otherwise) in our dealings with others and with texts that can lead us into error, and rather than try to escape from this fact, as Husserl did, Gadamer says that we should instead bring that into the play of interpretation. ${ }^{29}$ This uncertainty is everywhere apparent in the 
writings of Plato. Socrates over and over again qualifies his dialectical engagements by saying that he is "omitting much," even if he does not quite know what he is leaving out. ${ }^{30}$ And in Plato's Apology Socrates claimed that his wisdom lay in the fact that he knew that he did not know. ${ }^{31}$ We will never escape our own opinions, but we can allow ourselves the risk of being wrong.

Aristotle could not tell his pupils the exact way to a virtuous life for these same reasons. The virtuous life is, among other things, playful engagement with others, bouncing interpretations off one another in metheris, and being open to whatever might come out of such games. What does come out of these elements of the virtuous life is essentially negative, in that we destroy what was previously thought to be "typical" or a correct generalization..$^{32}$ The destruction of these generalizations took place over and over again in the early Platonic dialogues, as Socrates proved that Euthyphro did not know what piety is, Meno did not know what virtue is, and so on. The playful Socratic dialectic is the solution to the Aristotelian problem of ethical knowledge, for Socrates knew that virtue is not taught by teachers, ${ }^{33}$ but arrived at through play.

Notice that this playfulness is not a random "playing at" in which anything goes, nor is truth a function of whatever set of metaphors we decide to incorporate as rules in our play, as the popular stereotype of postmodern thought holds.. Play is often very serious because it is an exploration of truth, yet truth cannot appear if we do not allow ourselves to be open to it. The negative element of play creates a clearing in which truth can appear, and its constant interaction back and forth adapts itself to the increase in being that universals undergo. Wachterhauser observes:

When, however, a person of practical wisdom [phronesis] revises a universal ethical norm in light of new circumstances, this does not show that the identity of the universal itself has simply changed, but rather it has been "applied" in a new way to new circumstances. This does not imply that we are now dealing with a new and different universal; it shows instead the possibilities of meaning inherent in the universal itself. ${ }^{.4}$ 
Gadamer and Wachterhauser are not claiming that everything is subjective and that the world lacks ethical norms, but rather that those norms are living, growing things.

The Nicomachean Ethics is a set of general guidelines that shows us how to participate in phronesis the way Socrates would. Plato shared this attitude. ${ }^{35}$ By having Socrates claim that he "did not know" at the same time as he engaged in endless debate in the dialogues and the Republic, he was pointing beyond what the actual dialogues "said" and instead extended an invitation to participate in them. "In the process of recapitulation and repetition, in the repeated inducement to participate in the movement of dialectical discourse," writes Coltman, "the dialogues perform their ethical and pedagogical task-a task carried out via a maieutic or (re)productive mimesis." 36 In writing the dialogues Plato recognized this positive mode of mimesis; furthermore, other poets could also recognize it and actually practice virtue rather than endanger it.

An objection needs to be addressed regarding phronesis in our discussion thus far. Many scholars regard the Greek concept of phronesis as not free from ambiguity. To put the objection more exactly, some believe Aristotle and Plato mean different things by phronesis. Gadamer himself acknowledges that Aristotle was the first to separate the ideas of sophia and phronesis and elaborate on their distinction. In separating these ideas, Aristotle put forward the idea of ethics as a discipline distinct from metaphysics. Beyond the criticism that these conceptual distinctions simply were not there for Plato, there is also the fact that Aristotle heavily criticized Plato for holding a doctrine that, in subsuming practical under theoretical wisdom, tends towards "an empty generality."37 This conceptual confusion leads to an even greater misunderstanding of the nature and pursuit of the Good. How can we treat phronesis as an Aristotelian concept with Platonic implications if this disagreement is present?

The full answer to this problem must await the more complete discussion of my conclusion. For now, however, consider what Gadamer has called the "Platonic-Aristotelian unitary effect.".3. This "effect" arises when we compare what Aristotle said and what Plato did. Aristotle, in such passages of the Nicomachaen Ethics 
as we have considered previously, held that insofar as ethics is regarded as a "science" it is concerned with experience gained by interaction with the world; it is a comportment that engages the world to extract its truths. I argue that Plato, in writing the dialogues-especially the early ones-shows us precisely how this is done in the actions of Socrates. Socrates engages the world of people who claim to know, and he becomes involved in conversation with them. He asks hard questions, questions that initially appear easy and a matter of empirical finding, such as "What is justice?" and "What is piety?" In the course of dialectic we discover that such truths of the world are not easy to find, but we do not fault Socrates for not finding them. We bracket the issue of theoretical wisdom, and instead Plato draws us into the folds of practical wisdom, the activity of what is to be done. If we separate what Socrates discovered to be the case from how he went about discovering it, the Aristotelian distinctions appear in a more artful and rhetorically richer form. Zdravko Planinc writes,

When the descriptions of Socrates' phronesis in Plato's dialogues are compared with the distinctions made in Aristotle's ethical writings between theoretical, practical, and technical knowledge, the similarity between the Socratic aspiration to the good and Aristotelian phronesis is evident. ${ }^{31}$

The "effect" thus achieved in taking a more hermeneutic view of Plato and Aristotle, in addition to the merely philosophical or philological, places the idea of phronesis on firm ground that allows for defense of the poets.

\section{Part IV: Plato the Master Poet}

James Carse has observed that Plato wanted the poets to serve a role in the polis that stems from their ability to deceive the citizenry:

The danger of poets, for Plato, is that they can imitate so well that it is difficult to see what is true and what is merely invented. Since reality 
cannot be invented, but only discovered through the existence of reason-according to Plato-all poets must be put into the service of reason. The poets are to surround the citizens of the Republic with art as will "lead them unawares from childhood to love of, resemblance to, and harmony with, the beauty of reason."

The use of the word 'unawares' shows Plato's intention to keep the metaphysical veil intact. Those who are being led to reason cannot be aware of it. They must be led to it without choosing it. Plato asks his poets not to create, but to deceive (\$49). +1)

Carse represents a typical reading of Plato. After all, it was Plato who had Socrates banter on and on about what is allowed for poets to say and what should be censored. Furthermore, if a foreigner were to enter the polis and begin to speak of the things reason has told us to forbid, we shall "tell him there is no one like him in the city and that it isn't lawful for there to be" (Republic, III, 398a). Reason, on this reading of Plato, must counteract the violence done by the false virtue taught by poets who disguise these teachings. Poets are to be employed in this grand scheme.

To be sure, Carse thinks that this sort of deception is exploitation of the poets at its worst. Poets do not "display their art so as to make it appear real; they display the real in a way that reveals it to be art." +1 There cannot be anything more despicable than to ask (indeed, to command) the poets to do something against their nature in order to fulfil an agenda; in other words, to ask them to deceive rather than to display. Deception of this kind is achieved by submitting others to the authority of the text; that is, to engage in aesthetic mimesis. While Carse is right when he says that poets do display the real in a way that reveals it to be art, he is wrong in his negative assessment of what Plato was trying to accomplish, and in saying that it does not fit with the Plato's overall way of thinking. Plato's dominant concern for advocating censorship of the poets lay in the deeper purpose of removing the harmful ef- 
fects of aesthetic mimesis. Plato objected to the using the poets for a political purpose; he did not endorse that manipulation as Carse charges. To see that Plato and Carse may in fact be on the same side on this issue, and how Plato avoids apparent hypocrisy, consider what Gadamer says about art, remembering that poetry is one of its many forms.

Like Carse, Gadamer sensed an overriding playfulness in art. Mimesis has an important role in dialogue, just as it does in art: "Inasmuch as nature is without purpose and intention, just as it is without exertion, it is a constantly self-renewing play, and can therefore appear as a model for art." 42 What we are playing, according to Gadamer, is a game, one that has no end (Carse calls games of this sort, appropriately enough, "infinite games"). What makes such games "infinite" is that they are never finished, just as Being is never finished. Being can always be added-to, expanded and enlarged. As activities of properly pedagogical mimesis, infinite games are not a show for an audience, though they may inadvertently attract one. Instead, they are invitations to play, to observe the art and to participate in it by interpreting it. "Indeed," writes Gadamer, "contests are in danger of losing their real play character precisely by becoming shows." +3 Art is a never-ending game that requires the interaction of players who do not act out a script but rather engage each other with openness.

What are the rules of this game, and what is its goal? How do we decide who has won? Unlike other ("finite") games, art has no winner and no specific goal. The rules are set by players during the course of play, and can be changed. ${ }^{+4}$ This account may overwork the play metaphor. An alternative is to look at art from a hermeneutic standpoint. A work of art is a text, one we are always already interpreting when we are in its presence. When we engage the text, that is, behold the art and enter the game, we interact with a variety of "players." These players include the artist, the person interpreting the text, the whole ensemble of people who have constructed their own interpretations of the work, and so on. This is the "fusion of horizons" Gadamer refers to, a sort of gathering on the playing field of all the participants in the game of art. The players remain distinct only in their various Wirkungsgeschichte, but even this distinction they surrender when the play begins, be- 
cause it is added to in the progression of play. Similarly, I add to the being of the text as well, just as any player adds their play to a game to make it what it is. Thinking about baseball is also thinking about the players who have added to it, the Babe Ruths and Mickey Mantles of the game.

Just as baseball is transformed (both in terms of rules of play and style) and is played differently as time goes on and players are added, a work of art is only fully (but not finally) realized each time it is interpreted; that is, the fullness of its being is only to be had by adding to it. Gadamer writes,

Play is structure-this means that despite its dependency on being played it is a meaningful whole which can be repeatedly presented as such and the significance of which can be understood. But structure is also play, because-despite this theoretical unity-it achieves its full being only each time it is played. ${ }^{45}$

Gadamer is making a crucial distinction that requires careful notice. A work of art has a unity that can be taken up and interpreted; otherwise, it would make no sense to refer to it or anything else as a "text." However, the non-theoretical unity of full being exists only insofar as it is continually brought back into play and added to. If the Mona Lisa were lost along with all of its replications and no one ever saw it again, it would not cease to be. However, it would be effectively "stunted" in that it would cease to be added to; it would be a painting on canvass now lost and not art. A similar effect would be achieved if we simply ignored it as a work of art. The emphasis here is on the creation of and interaction with art, the activity and play that goes along with engaging a work in dialogue. Since there is no definitive interpretation of the Mona Lisa, or a "stopping point" for its increase in being, there is a strong intuition that the Mona Lisa exists only as a work in progress, an object in flux or a Form that is dependent upon its continual reinterpretation. When discussing the painting itself, it is more accurate to describe the talking going on as the Mona Lisa rather than what is said or the colors on canvas in front of us. The only 
way for it to survive is through re-creation, where "every repetition is as original as the work itself." +16

Here is the second critical distinction to be made in constructing my defense of the poets. The first was the distinction between aesthetic and properly pedagogical mimesis. The second is the difference between poiesis (creating) versus poiema (what is created). True art is not the paint on canvas but the ongoing recreation of the original act of genius; the true text is not the container of meaning but the dialogue in which I engage; the true game of baseball is not a summary of its rules or a compilation of its historical games played at certain times and places, but the playing of it by players. The poiema is useful only insofar as it points beyond itself and serves as an invitation to play, to continue the infinite game of poiesis. Plato's Republic, his written work that has Socrates recommend the removal of imitators and the bending of the poets to the dictates of reason, is a poiema that calls attention to something beyond itself. What it calls attention to is what it is doing, not what it says. Like Plato's dialogues, it is a demonstration of what the dictates of reason are: not a set of rigid rules to be discovered by the elect and enforced upon the poets and distributed to the masses through deception, but the activity of dialectic, the infinite dialogue whose goal is not "getting it right" in some final sense but getting it to continue.

The Republic, then, is itself a work of art, of poetry or poiema that points beyond itself by displaying how reason is cultivated. Deception of the citizens by poets is merely a suggestion, an explored possibility that enters into the dialogue and is tested for consistency and completeness, two Gadamerian criteria for valid interpretation. The objection arises: how can these arguments be merely suggestions if Plato goes to great lengths to defend this position? The answer is simple: Plato is not arguing "for" the position as much as he is inviting us to put it on trial. Why else would he make the concession of Book X, inviting us to defend the poets and argue for their inclusion in the polis? The reason is not that Plato particularly liked or admired the poets, although he probably did. Nor is it that Plato is acting out of philosophical snobbery, issuing a challenge meant to intimidate his audience into accepting his position rather than trying to argue against it. We must take 
Plato at his word here, because his invitation to defend the poets is what lies behind the poiema: a proposal for the audience to become players and to instantiate the display of poiesis. This device is most effective in combating what Carse and Plato both fear: deception. Only when we "lose ourselves to the game" as Gadamer puts it by becoming the poetry can we become immunized against its being used as a virus against us. ${ }^{47}$ Therefore, poetry cannot, properly speaking, be "utilized" at all qua poiesis. Only its abstraction, the poiema, can be mobilized against us.

Any other encounters with poetry risk its abuse. Carse calls ideas abstracted from a thinker "metaphysics" in a pejorative sense of the term. ${ }^{+8}$ Metaphysics is calling attention to the work of a thinker; it is the aesthetic mimesis described earlier. This bad side of metaphysics that potentially affects all poetry is what Plato warns against. In a way, he must also warn us against the Republic itself. Gadamer observes

Thus the poetry of Plato's dialogues is certainly not the model for that poetry which would be allowed in the ideal state. But it is the real poetry which is able to say what is educational in actual political life. And just as poetry in the ideal state must fend off aesthetic misinterpretations of its mimesis, Plato's dialogical poetry must resist any aesthetic misinterpretation. ${ }^{\text {'1 }}$

The proper role of poetry is not to instruct by telling, because as Socrates found out, poets do not know anything. ${ }^{\text {si }}$ Rather, it is to get others involved in conversation and community.

This point about poiesis and poiema contains the final and greatest bit of irony that smiles through the genius of Plato. In asking the question in Book X, and in having Socrates place the gauntlet at our feet, Plato has simultaneously issued a challenge, an invitation, and the answer to that challenge. Defending poets is accomplished by defending what they do, and the best way to do that is to create poetry ourselves, which is precisely what Plato always did. Carse himself suspected Plato of such cleverness: 
We must remind ourselves, to be sure, that Plato himself was an artist, a poietes... we cannot help but think that behind the rational metaphysician, philosophy's great Master Player, stood Plato the poet, fully aware that the entire opus was an act of play, an invitation to readers not to reproduce the truth but to take his inventions into their own play, establishing the continuity of his art by changing it (\$49).

The playing back and forth, the dialogue that changes and surprises and delights, these are just the things that we do to reach the Good, the "unity of what is unitary" as Gadamer says. "Unity" here has a double meaning: in the context of hermeneutics, it describes valid interpretation that does not overlook crucial aspects of the text. In a broader sense, "unity" is the principle that unites, the methexis that brings us together in dialogue so that interpretation is possible at all, so that poetry and creation are possible at all. We must talk about art and philosophy in close proximity to one another because of their mutual concern for truth, which is as Gadamer shows us located in the activity of art. Indeed, the questions of philosophy "never stray far from the topic of art" and often find their answers in it. ${ }^{51}$ As art, poetry initiates the conversation that philosophy takes up and makes its own.

The idea of the previous section was that the playfulness of poetry and dialogue contains within it a seed of seriousness that prevents it from being "mere" play. This idea reaches full fruition in light of what is now concluded about Plato's work. Gadamer tells us that

Precisely because of the seriousness of his purpose, Plato gives his mimesis the levity of a jocular play. Insofar as his dialogues are to portray philosophizing in order to compel us to philosophize, they shroud all of what they say in the ambiguous twilight of irony. And in this way Plato is able to escape the trap of the ever so vulnerable written work, which cannot come to its own de- 
fense, and to create a truly philosophical poetry which points beyond itself to what is of real consequence. His dialogues are nothing more than playful allusions which say something only to him who finds meanings beyond what is expressly stated in them and allows these meanings to take effect within him. ${ }^{52}$

This is why poetry is beneficial to human life. Plato, as master philosopher, posed question after question in pursuit of the truth; as a poet of genius, he extended an invitation to reply and to join in the wonder of infinite play.

\section{Notes}

' All quotations from the Republic are from the translation by G.M.A. Grube (Indianapolis: Hackett Publishing Company, Inc.), 1992.

' I do not consider it necessary to prove that poetry is pleasurable, as Socrates (Plato) already appears to be convinced of this point.

${ }^{3}$ Rod Coltman, The Language of Hermeneutics: Gadamer and Heidegger in Dialogue (Albany: State University of New York Press, 1998), p. 51.

${ }^{4}$ Hans-Georg Gadamer, "Plato and the Poets," in Dialogue and Dialectic: Eight Hermenentical Studies on Plato, trans. P. Christopher Smith (New Haven: Yale University Press, 1980), p. 63. [Hereafter abbreviated PP.]

\section{${ }^{5}$ Ibid.}

${ }^{6}$ Here we may ask ourselves whether the poet who engages in aesthetic mimesis is truly a poet, rather than a rhetorician or politician. The answer is no, for reasons that are made manifest in Part IV of this essay, where I introduce the distinction between poiesis and poiema.

${ }^{7}$ Hans-Georg Gadamer, Truth and Method, $2^{\text {nd }}$ ed. (New York: The Continuum Publishing Company, 1989), p. 340 [Hereafter abbreviated TM]: "The old unity of the hermeneutical disciplines comes into its own again if we recognize that historically effected consciousness is at work in all hermeneutical activity..."

${ }^{8}$ Iris Murdoch, The Fire \& the Sun (Oxford: Clarendon Press, 1977), pp. 13-14, 16.

${ }^{9} \mathrm{TM}$, p. 254 [emphasis mine]. 
"Ibid, p. 250.

"Ibid.

12 Coltman, p. 20.

${ }^{13}$ J.L. Ackrill, ed., A New Aristsole Reader (Princeton: Princeton University Press, 1987).

${ }^{14}$ This particularly Gadamerian reading of Aristotle is supported quite well by looking at the latter's analysis of equity, or epieikeia. See TM, p. 318.

${ }^{15}$ Kenneth Baynes, "Dialectic and Deliberation in Aristotle," in Southwest Philosophy Revieu' 6 (1990), p. 24.

${ }^{16}$ Coltman, p. 21.

17 Joseph Dunne, Back to the Rough Ground (Notre Dame: University of Notre Dame Press, 1993), pp. 158-159.

${ }^{18}$ For a discussion of the differences between episteme, techine, and phronesis, see Paul Schuchman, "Aristotle's Phronesis and Gadamer's Hermeneutics," in Philosophy Today, (Spring 1979): 41-50.

${ }^{19} \mathrm{TM}, \mathrm{p} .367$.

20 Francis Ambrosio, "Gadamer, Plato, and the Discipline of Dialogue," in International Philosophical Quarterly, I (1987), p. 23.

${ }^{21}$ Schuchman, p. 44.

2 Ambrosio, p. 23.

${ }^{23}$ Brice Wachterhauser, Beyond Being: Gadamer's Post-Platonic Hermeneutical Ontology (Evanston: Northwestern University Press, 1999), p. 147.

${ }^{24}$ Ibid [my emphasis].

${ }^{25}$ Ibid.

${ }^{26} \mathrm{TM}, \mathrm{p}$. 306-307.

${ }^{27}$ Ibid, p. 143.

${ }^{28}$ Ibid, p. $36 \mathrm{I}$.

${ }^{29}$ Ibid, p. 300-301.

${ }^{311}$ See, for example, Republic (VI, 509c)

${ }^{31}$ Plato, Apology, taken from Five Dialogues. G.M.A. Grube, trans. (Indianapolis: Hackett Publishing Company, 1981), 21d-e.

32 TM, p. 353.

${ }^{33}$ Plato, Meno, taken from Five Dialogues. G.M.A. Grube, trans. (Indianapolis: Hackett Publishing Company, 1981), 96a-d.

${ }^{34}$ Wachterhauser, p. 147.

${ }^{35}$ For an excellent argument for why Aristotle's notion of phronesis is indistinguishable from Plato's notion of dialectic, I refer the reader again to Kenneth Baynes, "Dialectic and Deliberation in Aristotle," from Southwest Philosophy Review 6 (1990): 19-42.

${ }^{36}$ Coltman, p. 55. 
${ }^{37}$ TM, p. 312.

${ }^{3 x}$ Hans-Georg Gadamer, The Idea of the Good in Platonic-Aristotelian Philosophy (New Haven: Yale University Press, 1986).

${ }^{39}$ Zdravko Planinc, Plato's Political Philosophy: Prudence in the Republic and the Laws (Columbia: University of Missouri Press, 1991), p. 9.

+1 James Carse, Finite and Infinite Games (New York: Ballantine Books, 1986).

"I lbid.

12 TM, p. 105.

${ }^{43}$ Ibid. p. 109.

" Carse, $\$ \$ 6,10$.

${ }^{45}$ Ibid. p. 117.

th Ibid. p. 122.

${ }^{47} \mathrm{TM}, \mathrm{p} 102$.

${ }^{4 *}$ Carse, $\$ 50$.

49 PP, p. 67.

50 Plato, Apology, 22a-d.

sI James Risser, Hermenentics and the Voice of the Other: Re-reading Gadamer's Philosophical Hermeneutics (Albany: State University of New York Press, 1997), p. 185.

${ }^{52} \mathrm{PP}, \mathrm{p} .71$. 